\title{
Determination of Morphological Variability among Cabbage (Brassica oleracea var. capitata L.) Hybrids and Their Parents
}

\author{
Beyhan KİBAR ${ }^{1}$, Onur KARAAĞAÇ², Hayati KAR ${ }^{2}$
}

\begin{abstract}
This study carried out to determine morphological traits of new experimental hybrids of cabbage and their parents. To determine morphological variability among tested hybrids and parents, they were analyzed for 34 morphological traits using Principal Component Analysis (PCA) and Cluster Analysis (CA). Results of the PCA indicated that the first three principal components accounted for $39.76 \%$ of the total variability among the 28 cabbage hybrids and $45.34 \%$ of the total variability among 22 cabbage parents for all the traits investigated. The first principal component (PC1) were the most important component and cabbage traits that constitute the PC1 (such as plant height, plant diameter, weight of head, diameter of head and length of head) were in fact the characteristics considered by breeders to be of greatest importance in cabbage breeding. At the result of CA, the cabbage hybrids were divided into eleven clusters and the cabbage parents were divided into nine clusters. PCA and CA confirmed that the cabbage hybrids and their parents were highly variable and had principally a significant variation for yield and yield components.
\end{abstract}

Keywords: Breeding, cabbage, cluster analysis, morphological variation, principal component analysis

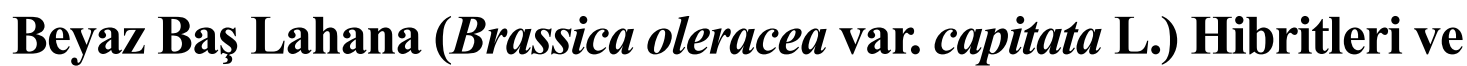 Onların Ebeveynleri Arasındaki Morfolojik Varyabilitenin Belirlenmesi}

ÖZET: Bu çalışma, yeni deneysel beyaz baş lahana hibritleri ve onların ebeveynlerinin morfolojik özelliklerini belirlemek için yürütülmüştür. İncelenen hibritler ve ebeveynler arasındaki morfolojik varyabiliteyi belirlemek amacıyla hibritler ve ebeveynler 34 morfolojik özellik için ana bileşen analizi ve kümeleme analizi ile analiz edilmiştir. Ana bileşen analizinin sonuçları ilk üç temel bileșenin araştırılan tüm morfolojik özellikler için 28 beyaz baş lahana hibriti arasındaki toplam varyabilitenin \%39.76'sını ve 22 beyaz baş lahana ebeveyni arasındaki toplam varyabilitenin \%45.34'ünü açıkladığını göstermiştir. İlk temel bileşen en önemli bileşen olarak bulunmuştur ve onu oluşturan özellikler (bitki boyu, bitki eni, baş ağırlığı, baş çapı ve baş yüksekliği) aslında lahana islahında ıslahçılar tarafından en büyük öneme sahip özellikler olarak düşünülmektedir. Kümeleme analizinin sonucunda beyaz baş lahana hibritlerinin 11 grupta ve ebeveynlerin 9 grupta kümelendiği belirlenmiştir. Ana bileşen analizi ve kümeleme analizi beyaz baş lahana hibritleri ve onların ebeveynlerinin oldukça değişkenlik gösterdiğini, verim ve verim bileşenleri için önemli bir varyasyona sahip olduklarını doğrulamıştır.

Anahtar kelimeler: Islah, lahana, kümeleme analizi, morfolojik varyasyon, ana bileşen analizi

\footnotetext{
Abant İzzet Baysal Üniversitesi, Ziraat ve Doğa Bilimleri Fakültesi, Bahçe Bitkileri Bölümü, Bolu, Türkiye

Karadeniz Tarımsal Araştırma Enstitüsü, Bahçe Bitkileri Bölümü, Samsun, Türkiye

Sorumlu yazar/Corresponding Author: Beyhan KİBAR, beyhan.kibar@ibu.edu.tr
} 


\section{INTRODUCTION}

Cabbage (Brassica oleracea var. capitata L.) is one of the most widely grown and important vegetable crops of Brassicaceae family consumed worldwide. The wide adaptability and easy-to-grow character of cabbage are no doubt responsible for the worldwide popularity of cabbage cultivation. In addition to their economic importance, the cabbage group vegetables (white, red and savoy cabbages, kale, broccoli, cauliflower, Chinese cabbages, Brussels sprouts and kohlrabi) are considered vital sources of vitamins, fibers, minerals (Rubatzky and Yamaguchi, 1997; Singh et al., 2010) and anti-carcinogenic compounds (Rosa et al., 1997; van Poppel et al., 1999).

The north European countries, the Baltic Sea coast (Monteiro and Lunn, 1998), and the Mediterranean region (Vural ve ark., 2000) are considered as centre for origin of cabbage. The Van region in Anatolia is thought to be the origin of the white head cabbage by Zhukovsky and the greatest cabbages of the world have been grown in this region (Bayraktar, 1981; Vural ve ark., 2000).

Cabbage production of Turkey in 2015 is 514344 tons and most of the production $(20.5 \%)$ is provided from Samsun province in the Black Sea Region situated in the north of Turkey (TÜİK, 2015).

It is necessary to have appropriate cultivars for intensive cabbage production. Although, the traditional local cabbage landraces which are open pollinated populations have been widely cultivated in Turkey formerly, in recent years, these populations were rapidly replaced by many modern hybrid cultivars. Compared with the populations of Turkish cabbage, commercial hybrids are preferred because of uniformity, vigorous development, high yield, high income, high quality and high field durability. Nowadays, cabbage production in Turkey totally depends on foreign hybrid cultivars, which are mainly imported from Germany and Netherlands since no competitive local hybrids have been developed so far.

Yanmaz ve ark. (2000) introduced that the potential of cabbages genetic resources in Turkey with their work and stated that this wealth should be evaluated. Cabbage breeding studies at the Black Sea Agricultural Research Institute in Samsun were begun with a comprehensive collecting programme for the cabbage populations of Turkey in 1998.
Morphological traits have been widely used for the selection of lines with maximum variation for plant breeding programmes (Liu et al., 2007; Hartings et al., 2008; Zhang et al., 2008; Smykal et al., 2008). Morphological characterization is the first step in the description and classification of the germplasm (Smith and Smith, 1989). The multivariate analysis particularly PCA and CA are applied especially in genetic divergence studies and for evaluation of germplasm when studying various traits and a large number of accessions (Crochemore et al., 2003; Cerqueira-Silva et al., 2009; Viana et al., 2010). Results obtained from such analyses are very important for developing and recommending of best cultivar for production in a specific area, as a selection criteria for further genetic improvements and can enable objective estimation of experimental genotypes, hence, developing best possible varieties for official testing by national registration authorities (Marjanovic-Jeromela et al., 2008).

A few studies on morphological characterisation in cabbage have been carried out by different researchers in Turkey (Balkaya et al., 2005; Kar ve ark., 2008; Kaygısız Aşçığul, 2009). However, there has not been any study about morphological characterisation of local cabbage hybrids and their parents using multivariate statistical analyses.

The objective of this study was to determine morphological variability in the cabbage hybrids and their parents, to show the structure of the variability and to group the characteristics possessing the highest level of variability using multivariate statistical analyses (Principle Component Analysis, Cluster Analysis).

\section{MATERIAL AND METHODS}

This study was conducted at the experiment field of Black Sea Agricultural Research Institute in Samsun province, Turkey (latitude $41^{\circ} 13^{\prime} \mathrm{N}$, longitude $36^{\circ} 29^{\prime} \mathrm{E}$ and altitude $6 \mathrm{~m}$ ) in 2010-2011 growing period. This location has a mild and humid climate with an annual rainfall of about $731 \mathrm{~mm}$, annual relative humidity of $70.8 \%$, and a mean annual air temperature of $16.5^{\circ} \mathrm{C}$ (minimum $8.4^{\circ} \mathrm{C}$ and maximum $28.4^{\circ} \mathrm{C}$ ) (Anonim, 2010).

The cabbage inbred lines used in this study were developed at the Black Sea Agricultural Research Institute after inbreeding for 7 to 10 generations and their seeds were collected formerly from different regions of Turkey or obtained from USDA (The United 
States Department of Agriculture). Their origins are presented in Table 1. A total of 50 cabbage materials were evaluated in this study. These included 22 inbred lines (Nos. 1 to 22) and 28 experimental hybrids (Nos. 1 to 28 ). The cross combinations used in the study are shown in Table 2.

Seeds of 50 cabbage materials (hybrids and their parents) were sown in multi-pot plastic trays consist of 45 pots $(4 \times 4 \times 4 \mathrm{~cm})$, containing a mixture of peat and perlite $(3: 1 \mathrm{v} / \mathrm{v})$ on 15 July 2010 . The seedlings were raised under plastic greenhouse conditions by the usual procedures. Thirty-three days later after sowing, twenty plants of each cabbage materials were transplanted into the open field at 4 true leaf stage on 18 August 2010. The experimental plots consisted of two rows of $7 \mathrm{~m}$ length with 10 plants in each row. Rows were spaced $100 \mathrm{~cm}$ apart and plants within rows were $70 \mathrm{~cm}$ apart. Conventional cultural practices were applied regularly during growing season.

Table 1. Origin and accession number of the cabbage inbred lines used in the study

\begin{tabular}{cccccc}
\hline Code & Accession Number & Origin & Code & Accession Number & Origin \\
\hline 1 & 531 Ç3 & Samsun & 12 & $508 \mathrm{~T}$ & Manisa \\
2 & BY 29 & Samsun & 13 & YBB 34 & Sakarya \\
3 & 506 Ç & Sakarya & 14 & 165 Ç & Samsun \\
4 & 4 Ç & Samsun & 15 & 180 & Bursa \\
5 & P 61 & USDA & 16 & 519 Ç & Tokat \\
6 & $115 \mathrm{~T}$ & İzmir & 17 & 542 & Sakarya \\
7 & $530 \mathrm{C}$ & Bursa & 18 & P 62-1 & USDA \\
8 & 145 & Niğde & 19 & 531 Ç1 & Samsun \\
9 & 148 & İzmir & 20 & P 19-1 & USDA \\
10 & 160 & Balıkesir & 21 & P 47-2 & USDA \\
11 & $166 \mathrm{~T}$ & Samsun & 22 & YBB 26 & Erzincan \\
\hline
\end{tabular}

Table 2. The experimental hybrids and their parents used in the study

\begin{tabular}{|c|c|c|c|}
\hline $\begin{array}{l}\text { Hybrid } \\
\text { No }\end{array}$ & $\begin{array}{l}\text { Parents } \\
\text { ( }+ \text { ( ) X }\left({ }^{\Uparrow}\right)\end{array}$ & Hybrid No & $\begin{array}{c}\text { Parents } \\
\text { (†) } X\left({ }^{\dagger}\right)\end{array}$ \\
\hline 1 & $1 \mathrm{X} 4$ & 15 & $2 \times 15$ \\
\hline 2 & $1 \times 5$ & 16 & $2 \times 16$ \\
\hline 3 & $1 \mathrm{X} 6$ & 17 & $2 \times 17$ \\
\hline 4 & $1 \times 7$ & 18 & $2 \times 18$ \\
\hline 5 & $1 \mathrm{X} 8$ & 19 & $3 X 4$ \\
\hline 6 & $1 \times 9$ & 20 & $3 \times 5$ \\
\hline 7 & $1 \mathrm{X} 10$ & 21 & $3 \times 8$ \\
\hline 8 & $1 \mathrm{X} 11$ & 22 & $3 X 15$ \\
\hline 9 & $1 \mathrm{X} 12$ & 23 & $3 \times 19$ \\
\hline 10 & $1 \mathrm{X} 13$ & 24 & $4 \mathrm{X} 1$ \\
\hline 11 & $2 \times 5$ & 25 & $4 X 19$ \\
\hline 12 & $2 \times 6$ & 26 & $4 \times 20$ \\
\hline 13 & $2 \times 7$ & 27 & $4 \times 21$ \\
\hline 14 & $2 \times 14$ & 28 & $4 \times 22$ \\
\hline
\end{tabular}


The plants were harvested for analysis when cabbage materials had completed head formation and all of the morphological properties were measured at the optimum time for consumption. According to different harvest periods of cabbage materials, the harvest started at the end of November of 2010 and lasted until the end of January of 2011. Morphological characterization were carried out on 10 plants harvested from each cabbage materials. All of the cabbage materials were evaluated for a total of 34 morphological traits (Table 3). Selection of traits and measurement techniques were based on International Union for the Protection of New Varieties of Plants (UPOV, 2004) and International Plant Genetic Resources Institute (IBPGR, 1990) descriptor lists developed for B. oleracea var capitata L.

Table 3. Morphological traits and their description used in the morphological characterization

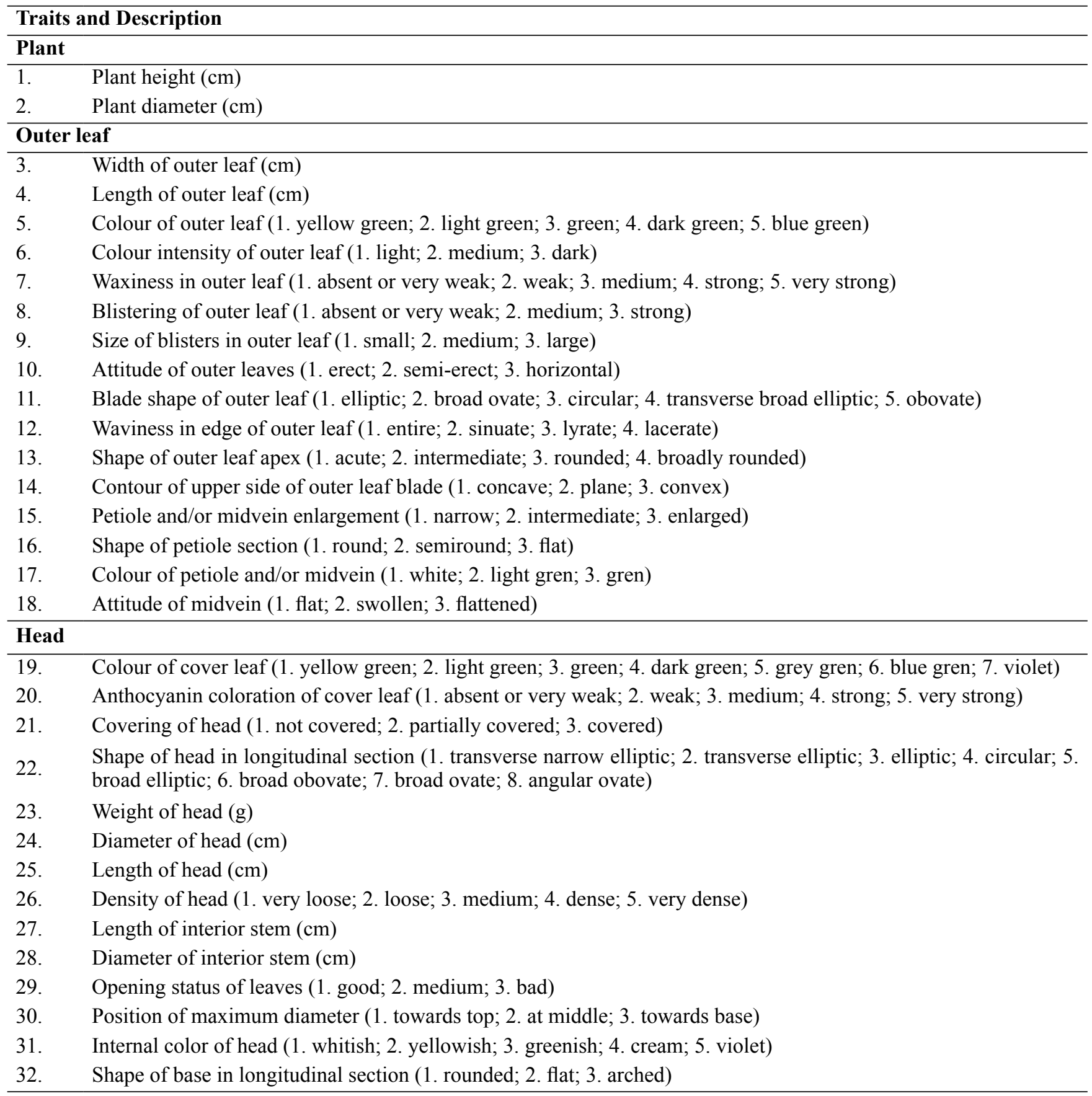

\section{Earliness and resistance to cracking}

33. Time of harvest maturity (days) (1. early; 2. medium; 3. late)

34. Durability of mature head in the field (days) (1. short; 2. medium; 3. long) 
In order to determine the morphological variation among hybrids and their parents, the obtained results were analyzed by using Principal Component Analysis (PCA) and Cluster Analysis (CA). PCA is a multivariate analytical method, which is used to downsize the dimensions of a data set, while maximally retaining its variability. CA is used to determine differences and similarities among the genotypes, and the distance measure used was Euclidean distance as the parameter that best reflects differences existing among the genotypes (Kendall, 1980; Gvozdanovic-Varga, 2004). PCA was carried out using SPSS (16.0). CA was performed by the unweighted pair-group method for arithmetic averages (UPGMA) method using the computer program NTSYS-pc, version 2.2 (Rohlf, 1992). The results of CA were presented in the form of dendrograms. The means and standard deviations for quantitative characters within each cluster were calculated to estimate the inter cluster variation.

\section{RESULTS AND DISCUSSION}

The trial involved 22 cabbage inbred lines, 28 experimental cabbage hybrids and 34 morphological traits. The Principle Component Analysis (PCA) was applied to identify the traits which were the main source of the variability and to explain the genetic diversity among hybrids and their parents. At the end of PCA, factor coefficients of identifying qualities were evaluated and the attributes scoring a coefficient value higher than 0.6 in the first three PCA were determined (Jeffers, 1967). The results of the PCA are presented in Table 4. The first three principal components (PCs) accounted for $39.76 \%$ of the total variability among the 28 cabbage hybrids for all the traits investigated. The first principal component (PC1), which is the most important component, explained $15.77 \%$ of the total variability and was related to plant height, plant diameter, width of outer leaf, length of outer leaf, weight of head, diameter of head and length of head. These traits have a great influence on the formation of yield. The second principal component (PC2) had 14.32\% of the total variation in morphological traits. Colour of outer leaf, colour intensity of outer leaf, waxiness in outer leaf and opening status of leaves contributed positively to PC2. In contrast, blade shape of outer leaf and length of interior stem contributed negatively to PC2. The third principal component (PC3) exhibited $9.68 \%$ of the total morphological variability and was associated with petiole and/or midvein enlargement and shape of petiole section (Table 4).
The fact that eigen values are above 1 indicates that the evaluated principle component weight values are reliable. CA is more sensitive and reliable when $25 \%$ of the total variation or more is explained by the first two or three axes in PCA (Mohammadi and Prasanna, 2003). In the our study, the first three principal components (PCs) explained $39.76 \%$ of the total variability.

Tanaka and Niikura (2003) analyzed the characteristics of early cabbage hybrids and grouped them on the basis of the PCA. These authors also obtained 4 major groups which shared the variance in the following way: PC1 52.3, PC2 13.1, PC3 9.1 and PC4 $7.0 \%$ of the total variance, and their cumulative variance amounted to $81.5 \%$. Cervenski et al. (2011a) used the PCA to determine variability of characteristics in new experimental hybrids of early cabbage. The first four principal components that explain $87.2 \%$ of the total variance. PC1 accounted for $45.3 \%$ of the variance. Seven traits had the highest communality with the first principal component and these were plant height, rosette diameter, the weight of the whole plant, head weight, the usable part of the head, head height and head diameter.

Our results show a group of three principal components, with similar percentages of variance. The highest percentage of variance is also in the first group, as in the case of the above authors. Our results are also in agreement with those of Vasic et al. (2008), Cervenski et al. (2011a, b) and Kaygısız Aşçığul (2009) who named the first principal component of the yield and yield components.

PCA of cabbage traits studied for cabbage parents focused on the variability of the first three principal components. Results of the PCA indicated that the first three principal components explained $45.34 \%$ of the total variability among the 22 cabbage parents. The first principal component (PC1) had $20.23 \%$ of the morphological variation. Plant height, plant diameter, width of outer leaf, length of outer leaf, weight of head and diameter of head were important variables composing PC1. This is an indication of the importance of the yield components. The second principal component (PC2) exhibited $15.18 \%$ of the total morphological variability and was positively associated with colour of outer leaf, attitude of outer leaves, waviness in edge of outer leaf, colour of cover leaf and shape of base in longitudinal section. Whereas, shape of outer leaf apex was negatively associated with PC2. 
The third principal component (PC3) constituted $9.93 \%$ of the total variation and only contour of upper side of outer leaf blade contributed negatively to PC3 (Table 4). PCA demonstrated that the first three principal components could explain the total variance that was observed to a large degree. Lezzoni and Pritts (1991) stated that when principle component analysis explains the majority of the variation of the first two or three components it would be a very suitable technique for grouping.

Table 4. Principal component analysis (for the first three PCs) of cabbage traits studied for cabbage hybrids and parents (Characters with high coefficients in the PC axes should be considered more important, thus eigen vectors above 0.60 are shown in bold)

\begin{tabular}{|c|c|c|c|c|c|c|}
\hline & & & & & & \\
\hline & & Hybrids & & & Parents & \\
\hline & PC 1 & PC 2 & PC 3 & PC 1 & PC 2 & PC 3 \\
\hline Eigen values & 5.360 & 4.868 & 3.290 & 6.879 & 5.160 & 3.377 \\
\hline Proportion of variation (\%) & 15.766 & 14.318 & 9.677 & 20.232 & 15.177 & 9.931 \\
\hline Cumulative variation (\%) & 15.766 & 30.084 & 39.761 & 20.232 & 35.410 & 45.341 \\
\hline Traits & & & Eigen & ectors & & \\
\hline Plant height & 0.831 & 0.067 & 0.208 & 0.704 & -0.289 & 0.161 \\
\hline Plant diameter & 0.668 & 0.258 & -0.054 & 0.739 & 0.038 & 0.443 \\
\hline Width of outer leaf & 0.860 & 0.157 & 0.194 & 0.662 & 0.426 & -0.211 \\
\hline Length of outer leaf & 0.778 & 0.091 & -0.132 & 0.838 & 0.112 & -0.031 \\
\hline Colour of outer leaf & -0.028 & 0.770 & -0.006 & 0.355 & 0.615 & 0.442 \\
\hline Colour intensity of outer leaf & 0.147 & 0.731 & 0.340 & 0.579 & 0.365 & 0.224 \\
\hline Waxiness in outer leaf & -0.040 & 0.632 & -0.348 & 0.383 & 0.137 & 0.175 \\
\hline Blistering of outer leaf & 0.333 & 0.423 & 0.146 & 0.445 & 0.209 & -0.145 \\
\hline Size of blisters in outer leaf & 0.116 & 0.304 & 0.190 & 0.264 & -0.251 & -0.459 \\
\hline Attitude of outer leaves & -0.432 & 0.041 & -0.388 & -0.232 & 0.684 & -0.151 \\
\hline Blade shape of outer leaf & 0.163 & -0.757 & 0.261 & 0.243 & -0.413 & -0.329 \\
\hline Waviness in edge of outer leaf & -0.248 & -0.234 & 0.030 & -0.337 & 0.611 & 0.278 \\
\hline Shape of outer leaf apex & -0.012 & 0.034 & 0.517 & -0.354 & -0.694 & 0.138 \\
\hline Contour of upper side of outer leaf blade & -0.180 & 0.024 & 0.002 & 0.144 & 0.359 & -0.608 \\
\hline Petiole and/or midvein enlargement & 0.062 & 0.050 & 0.697 & 0.422 & 0.321 & -0.313 \\
\hline Shape of petiole section & -0.200 & -0.034 & 0.673 & -0.095 & -0.329 & -0.316 \\
\hline Colour of petiole and/or midvein & -0.303 & 0.199 & -0.448 & 0.012 & -0.420 & -0.092 \\
\hline Attitude of midvein & 0.091 & -0.220 & 0.226 & -0.350 & -0.002 & 0.553 \\
\hline Colour of cover leaf & -0.054 & 0.355 & 0.017 & -0.311 & 0.838 & 0.028 \\
\hline Anthocyanin coloration of cover leaf & -0.179 & -0.102 & 0.384 & -0.164 & -0.212 & 0.382 \\
\hline Covering of head & -0.053 & 0.098 & 0.357 & -0.582 & -0.483 & 0.040 \\
\hline Time of harvest maturity & 0.271 & -0.280 & -0.375 & 0.076 & -0.710 & 0.236 \\
\hline Durability of mature head in the field & -0.003 & -0.169 & 0.081 & -0.564 & 0.273 & -0.002 \\
\hline Shape of head in longitudinal section & -0.248 & 0.042 & 0.197 & -0.005 & -0.216 & 0.116 \\
\hline Weight of head & 0.784 & -0.312 & -0.075 & 0.827 & 0.061 & 0.247 \\
\hline Diameter of head & 0.747 & -0.348 & -0.128 & 0.636 & -0.024 & 0.393 \\
\hline Length of head & 0.678 & -0.431 & -0.059 & 0.559 & -0.341 & 0.402 \\
\hline Density of head & -0.176 & 0.568 & 0.325 & 0.433 & -0.115 & -0.434 \\
\hline Length of interior stem & 0.437 & -0.668 & 0.010 & 0.510 & -0.074 & -0.139 \\
\hline Diameter of interior stem & 0.413 & 0.557 & -0.078 & 0.304 & 0.080 & -0.080 \\
\hline Opening status of leaves & -0.180 & 0.664 & 0.309 & 0.318 & -0.022 & -0.556 \\
\hline Position of maximum diameter & -0.219 & 0.050 & 0.141 & 0.253 & -0.106 & 0.514 \\
\hline Internal color of head & 0.012 & 0.201 & 0.464 & -0.278 & 0.062 & 0.293 \\
\hline Shape of base in longitudinal section & 0.045 & -0.145 & 0.538 & -0.413 & 0.683 & 0.151 \\
\hline
\end{tabular}


In the study conducted by Kaygısız Aşçığul (2009), the first three principal components (PCs) explained $42.6 \%$ of the total variability among cabbage genotypes, which was collected from different regions of Turkey. PC1 accounted for $20.9 \%$, PC2 $12.5 \%$ and PC3 $9.2 \%$ of the total variation in 34 morphological traits. In the study, average head weight, yield, head size according to the plant, diameter of head, width of outer leaf, length of outer leaf were important variables composing PC1. Eigen values, proportion of variation and cumulative variation in our results are similar with values of Kaygısız Aşçığul (2009). Cervenski et al. (2011b) studied the diversity in Serbian local cabbage populations and 15 cabbage morphological traits analysed by using PCA. The first three principal components gave Eigen values greater than 1.0 and explained $99.99 \%$ of the total variability among the cultivars and populations for all the traits investigated. In the study, PC1 accounted for $50.2 \%$, PC2 $27.9 \%$ and PC3 $21.9 \%$ of the total variation in morphological traits.

For a successful breeding program, genetic diversity and variability play a vital role. It is a useful and essential tool for parents' choice in hybridization to develop high yield potential cultivars and to meet the diversified goals of plant breeding (Arslanoglu et al., 2011). PCA is useful as it gives information about the groups where certain traits are more important allowing the breeders to conduct specific breeding programs (Yousuf et al., 2011). Therefore, the parents should be selected considering results of PCA.

For a better overview of diversity in the cabbage hybrids and parents, CA was also used. The data to be used in the CA are evaluated taking also into consideration the PCA results. Genetic similarity among hybrids was estimated using UPGMA cluster analysis based on morphological traits. Dendrogram of cabbage hybrids obtained from CA is shown in Figure 1. In the dendogram, dissimilarity coefficients among hybrids ranged from 0.56 to 1.54 . At the result of CA based on thirty four morphological traits, the cabbage hybrids were divided into eleven clusters. Hybrids with greater similarity for morphological traits were placed in the same cluster. Among the eleven different clusters, the biggest group was Cluster D that include 14 hybrids, while cluster A,
G, H, I, J and K comprised only one hybrids. Cluster $\mathrm{B}, \mathrm{C}, \mathrm{E}$ and $\mathrm{F}$ contained two hybrids (Figure 1). It was determined that hybrids used as parent of 4 numbered genotype $(1 \times 4,4 \times 1,4 \times 20$ and $4 \times 22)$ had more different morphological structure according to other hybrids. To increase the variability, it is considered that more use of this genotype as parent in hybridizations in the future.

Cluster means and standard deviations for 34 traits in 28 cabbage hybrids are shown in Table 5. Head weight is a major component of the yield of cabbage. In the study, the values of head weight of the experimental hybrids ranged from $2073 \mathrm{~g}$ (Cluster C) to $5875 \mathrm{~g}$ (Cluster H). As weight of head, the highest diameter of head $(34 \mathrm{~cm})$ and length of head $(27 \mathrm{~cm})$ were found in cluster $\mathrm{H}$. On the other hand, Cluster $\mathrm{G}$ and $\mathrm{C}$ had the lowest diameter of head and length of head. Time of harvest maturity were considerably variable. Although, Cluster A and $\mathrm{G}$ were classified as early (103 days), Cluster $\mathrm{H}$ was classified as late (160 days). It may concuded that the late hybrids have bigger and heavier heads than the early ones. The hybrids in Cluster F and $\mathrm{J}$ had anthocyanin coloration of cover leaf which is an undesired property. Shape of head in longitudinal section of cabbage hybrids was mostly elliptic or transverse narrow elliptic (Table 5). The results of CA suggested that there is enough variation among the hybrids for different morphological traits. However, there were minimal variations among hybrids in some of the qualitative characters such as, waviness in edge of outer leaf, attitude of outer leaves and anthocyanin coloration of cover leaf. 


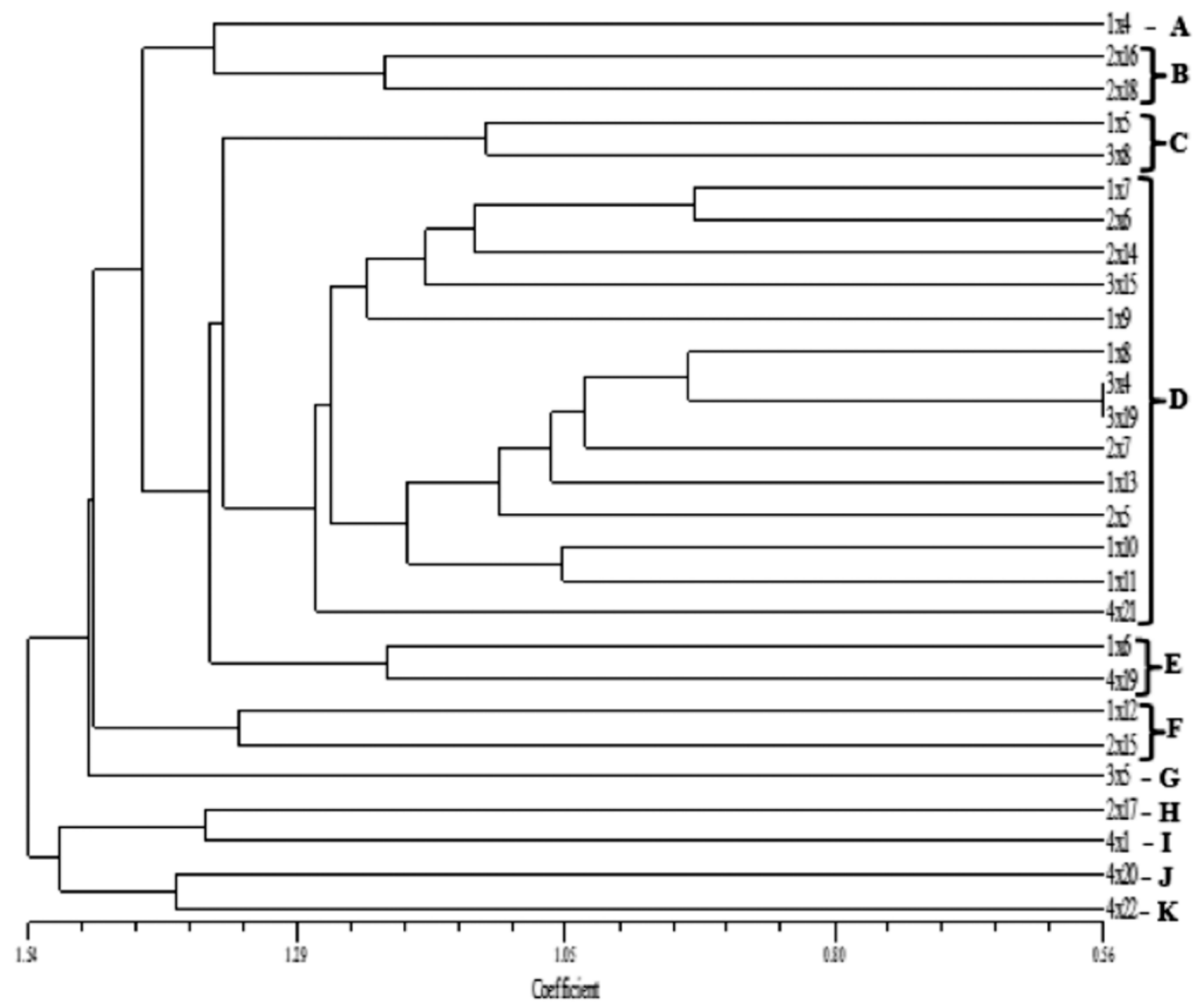

Figure 1. Dendrogram of cabbage hybrids obtained from cluster analysis based on morphological traits

In order to choose the best hybrids to be registered, differences among them are important. Weight of head, diameter of head, length of head, length of interior stem, opening status of leaves, internal color of head, anthocyanin coloration of cover leaf, covering of head, time of harvest maturity and durability of mature head in the field are economically important characters of cabbage. When taken into consideration above traits $1 \times 5,1 \times 8$, $1 \times 13,2 \times 18,3 \times 4,3 \times 19$ and $4 \times 21$ numbered hybrids were suitable for sarmalik (sarma is a traditional Turkish food prepared by wrapping cabbage leaf around rice and other products) production. We consider that $1 \times 6$ and $1 \times 12$ numbered hybrids are more suitable for pickled consumption. Therefore these hybrids were found to be promising for registration studies.

Cervenski et al. (2010) applied the method of hierarchical clustering to differentiate the experimental hybrids and commercial cultivars in cabbage as clearly as possible. The dendrogram clustered the genotypes on the basis of all characters under examination (head weight, usable part of the head, head diameter, yield). Two clusters were formed. The first included the experimental hybrids, two commercial cultivars (Futoški and SM-10) and one commercial hybrid (Coronet-F1). The second included the commercial hybrids and the other two commercial cultivars. 
Table 5. Mean values and standard deviations of 11 clusters based on 34 morphological traits of cabbage hybrids

\begin{tabular}{|c|c|c|c|c|c|c|c|c|c|c|c|}
\hline \multirow[t]{2}{*}{ Trait } & \multicolumn{11}{|c|}{ Clusters } \\
\hline & $\mathbf{A}$ & B & $\mathrm{C}$ & D & $\mathbf{E}$ & $\mathbf{F}$ & G & $\mathbf{H}$ & I & $\mathbf{J}$ & $\mathbf{K}$ \\
\hline 1 & 48.5 & $43.5 \pm 7.1$ & $36.5 \pm 2.1$ & $48.4 \pm 3.9$ & $50.5 \pm 6.4$ & $50.3 \pm 11.7$ & 48.5 & 48 & 59.5 & 43.5 & 43.5 \\
\hline 2 & 89 & $98.5 \pm 12.7$ & $84 \pm 4.2$ & $97.5 \pm 19.6$ & $91 \pm 12.7$ & $112 \pm 17.0$ & 92.5 & 109 & 109 & 86.5 & 79 \\
\hline 3 & 40.5 & $40.75 \pm 4.3$ & $32.25 \pm 1.8$ & $41.8 \pm 3.9$ & $41 \pm 4.2$ & $46.5 \pm 4.9$ & 40 & 43 & 47 & 40 & 32.5 \\
\hline 4 & 45 & $49.75 \pm 5.1$ & $42.5 \pm 3.5$ & $52.3 \pm 5.5$ & $48.8 \pm 1.8$ & $48 \pm 2.1$ & 50.5 & 56 & 58 & 40 & 39 \\
\hline 5 & 5 & 3 & 5 & $3,4,5$ & 4,5 & 5 & 4 & 3 & 3 & 3 & 3 \\
\hline 6 & 2 & 2,3 & 2 & 2,3 & 3 & 3 & 3 & 2 & 2 & 2 & 2 \\
\hline 7 & 4 & 4 & 4 & $2,3,4$ & 4 & 3 & 4 & 2 & 2 & 3 & 2 \\
\hline 8 & 1 & 1,3 & 2 & $1,2,3$ & 3 & 3 & 2 & 2 & 2 & 2 & 1 \\
\hline 9 & 1 & 2,3 & 2 & 2,3 & 2,3 & 3 & 1 & 1 & 2 & 3 & 1 \\
\hline 10 & 2 & 2,3 & 2,3 & 2,3 & 2 & 2 & 2 & 2 & 2 & 2 & 2 \\
\hline 11 & 3 & 3 & 1,3 & $1,3,5$ & 3 & 3 & 3 & 5 & 5 & 5 & 5 \\
\hline 12 & 2 & 1 & 2 & 2 & 2 & 2 & 2 & 2 & 2 & 2 & 1 \\
\hline 13 & 4 & 4 & 4 & $2,3,4$ & 3,4 & 3 & 3 & 4 & 4 & 4 & 4 \\
\hline 14 & 1 & 2 & 3 & 2,3 & 2,3 & 2,3 & 3 & 2 & 3 & 3 & 2 \\
\hline 15 & 3 & 2,3 & 1 & $1,2,3$ & 2,3 & 3 & 3 & 3 & 1 & 2 & 3 \\
\hline 16 & 2 & 2 & 1 & $1,2,3$ & 2,3 & 2 & 2 & 1 & 1 & 2 & 3 \\
\hline 17 & 2 & 2 & 1 & 2 & 1 & 2 & 2 & 2 & 2 & 2 & 2 \\
\hline 18 & 1 & 1 & 1,2 & $1,2,3$ & 1,2 & 2 & 2 & 2 & 2 & 2 & 2 \\
\hline 19 & 2 & 2,6 & 3 & $2,3,6$ & 3,6 & 3 & 2 & 3 & 3 & 3 & 3 \\
\hline 20 & 1 & 1 & 1 & 1 & 1 & 1,3 & 1 & 1 & 1 & 3 & 1 \\
\hline 21 & 2 & 3 & 3 & $1,2,3$ & 1,2 & 2,3 & 2 & 2 & 3 & 2 & 2 \\
\hline 22 & 3 & 3 & 3 & 1,3 & 1,3 & 3,4 & 3 & 3 & 1 & 4 & 3 \\
\hline 23 & 2615 & $4030 \pm 973.8$ & $2073 \pm 67.2$ & $3296 \pm 580$ & $3583 \pm 95.5$ & $3335 \pm 1435.4$ & 2230 & 5875 & 5545 & 3530 & 3150 \\
\hline 24 & 23.5 & $26.75 \pm 2.3$ & $22 \pm 0.7$ & $26.0 \pm 3.3$ & $26.8 \pm 3.2$ & $23 \pm 2.1$ & 21 & 34 & 33 & 26 & 22 \\
\hline 25 & 21 & $21 \pm 2.0$ & $17 \pm 1.4$ & $19.5 \pm 1.5$ & $21.3 \pm 0.4$ & $19.3 \pm 4.6$ & 17.5 & 27 & 24.5 & 25 & 18.5 \\
\hline 26 & 1 & 3,4 & 3 & $1,3,4$ & 3,5 & 4,5 & 5 & 3 & 2 & 3 & 3 \\
\hline 27 & 9.5 & $10 \pm 3.0$ & $7.75 \pm 0.4$ & $9.8 \pm 1.8$ & $6.5 \pm 0.7$ & $6.5 \pm 0.7$ & 6 & 11 & 13 & 14.5 & 8 \\
\hline 28 & 4 & $4 \pm 0.0$ & $3.25 \pm 0.4$ & $4.0 \pm 0.3$ & $4.3 \pm 0.4$ & $3.8 \pm 0.4$ & 4 & 4 & 3.5 & 3.5 & 3 \\
\hline 29 & 1 & 1,2 & 1 & 1,2 & 1,3 & 2,3 & 3 & 1 & 1 & 1 & 1 \\
\hline 30 & 3 & 2 & 2 & 1,2 & 2 & 2,3 & 2 & 2 & 3 & 2 & 2 \\
\hline 31 & 4 & 1,4 & 1 & 1,4 & 1 & 2,4 & 4 & 1 & 1 & 1 & 4 \\
\hline 32 & 1 & 1 & 1 & $1,2,3$ & 1 & 1,2 & 1 & 1 & 1 & 1 & 2 \\
\hline 33 & 103 & $119 \pm 11.6$ & $126 \pm 0.0$ & $112.5 \pm 4.6$ & $143 \pm 24.0$ & $108.5 \pm 7.8$ & 103 & 160 & 124 & 112 & 124 \\
\hline 34 & 30 & $30 \pm 5.0$ & $30 \pm 7.1$ & $30.7 \pm 4.3$ & $32.5 \pm 3.5$ & $32.5 \pm 3.5$ & 20 & 30 & 30 & 35 & 35 \\
\hline
\end{tabular}

Genetic grouping of 22 cabbage parents using the UPGMA clustering algorithm is shown in Figure 2. Looking at the dendrogram it can be observed that dissimilarity coefficients among parents ranged from 0.84 to 1.82 . The cabbage parents were divided into different clusters by their distribution on the dendogram. In the present research, nine clusters were occured at the result of the CA, in terms of morphological traits. Cluster A consisted of 5 genotypes. There was a total of 7 genotypes in Cluster B the biggest group. Cluster $\mathrm{C}$ had 3 genotypes. Cluster D contained two genotypes. However, there was only one genotype in Cluster E, F, G, H and I (Figure 2). 


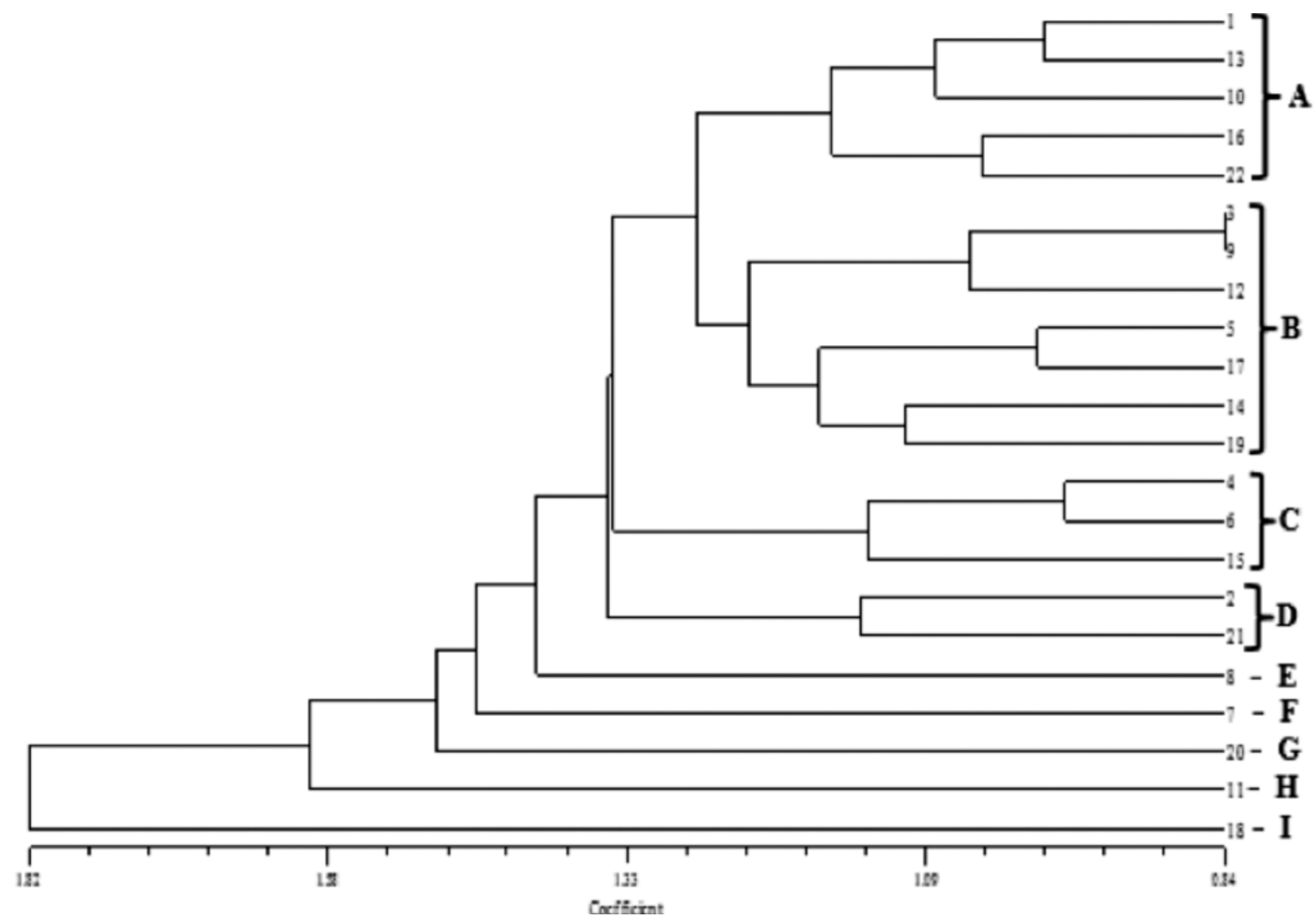

Figure 2. Dendrogram of cabbage parents obtained from cluster analysis based on morphological traits

Mean values and standard deviations for each cluster based on morphological traits of cabbage parents are presented in Table 6. In the study, the values of head weight of the parents ranged from $1530 \mathrm{~g}$ (Cluster F) to $3690 \mathrm{~g}$ (Cluster C). Although the highest mean for diameter of head and length of head were found in Cluster C, D and G, Cluster F and $\mathrm{H}$ had the lowest. When taken into consideration weight of head, diameter of head, length of head Cluster C, D and A can be used to develop a new hybrid cultivar. Since anthocyanin coloration of cover leaf is an undesired property, genotypes in Cluster F and $G$ should not be used as parent in hybrid cabbage breeding. Also genotype in Cluster F should not selected for hybrid cabbage breeding because it has not covered head. Cluster E, H and I were classified as early. These genotypes were harvested at 98 days. Cluster $\mathrm{F}$ was classified as late and harvested at 155 days (Table 6). The morphological variability among cabbage parents could be related primarily to their geographical origin. This variability is very important for breeding studies and the promising genotypes which has superior for important plant characteristics could be successfully utilized in breeding programs that are aimed to develop a new hybrid cabbage cultivar.

Balkaya et al. (2005) studied morphological variation in white head cabbage genotypes collected from different eco-geographical regions of Turkey. Cluster analysis based on 12 quantitative and 10 qualitative variables identified 10 groups. The dendogram was prepared to evaluate morphological similarity among the white head cabbage genotypes. Morphological variability was found high among the white head cabbage genotypes of Turkey. Similar conclusions were obtained by Kaygısız Aşçığul (2009) in a study that assessed morphological and molecular traits of 36 leaf and head cabbage genotypes, which was collected from different regions of Turkey. Results of present study are in agreement with those of Balkaya et al. (2005) and Kaygısız Aşçığul (2009). 
Table 6. Mean values and standard deviations of 9 clusters based on 34 morphological traits of cabbage parents

\begin{tabular}{|c|c|c|c|c|c|c|c|c|c|}
\hline \multirow{2}{*}{ Trait } & \multicolumn{9}{|c|}{ Clusters } \\
\hline & $\mathbf{A}$ & B & C & D & $\mathbf{E}$ & $\mathbf{F}$ & $\mathbf{G}$ & $\mathbf{H}$ & I \\
\hline 1 & $46.4 \pm 3.7$ & $48.3 \pm 6.7$ & $50.2 \pm 9.6$ & $54 \pm 5.7$ & 46 & 45 & 47 & 41 & 39.5 \\
\hline 2 & $102.7 \pm 22.7$ & $94.7 \pm 16.3$ & $106.5 \pm 28.7$ & $103 \pm 12.7$ & 81 & 73 & 118 & 90.5 & 88.5 \\
\hline 3 & $40.5 \pm 4.2$ & $34.6 \pm 6.2$ & $45.8 \pm 5.5$ & $41.5 \pm 0.7$ & 36 & 34 & 30 & 46 & 37 \\
\hline 4 & $49.1 \pm 4.6$ & $46.3 \pm 7.2$ & $57.2 \pm 11.3$ & $45.5 \pm 2.1$ & 42 & 36 & 47 & 48 & 39.5 \\
\hline 5 & $3,4,5$ & 3,5 & 4,5 & 3,4 & 3 & 3 & 4 & 5 & 4 \\
\hline 6 & 2,3 & 2,3 & 3 & 3 & 2 & 2 & 3 & 2 & 3 \\
\hline 7 & 3,4 & $2,3,4$ & 4 & 2,3 & 2 & 3 & 3 & 4 & 3 \\
\hline 8 & 2,3 & 1,2 & 2,3 & 1 & 2 & 1 & 2 & 3 & 1 \\
\hline 9 & 1,2 & 2 & 2,3 & 2 & 2 & 2 & 2 & 3 & 1 \\
\hline 10 & 2 & 2 & 2 & 2 & 2 & 2 & 2 & 3 & 3 \\
\hline 11 & 1,3 & $1,3,5$ & 5 & 3,5 & 5 & 3 & 1 & 3 & 3 \\
\hline 12 & 2 & 2 & 2 & 2 & 2 & 2 & 2 & 2 & 1 \\
\hline 13 & $2,3,4$ & $2,3,4$ & 4 & 4 & 4 & 2 & 3 & 4 & 4 \\
\hline 14 & 3 & 3 & 2,3 & 3 & 2 & 3 & 3 & 1 & 3 \\
\hline 15 & 2,3 & $1,2,3$ & 3 & 2,3 & 3 & 1 & 3 & 3 & 2 \\
\hline 16 & 1,3 & 1,2 & 1,2 & 1 & 2 & 1 & 1 & 1 & 1 \\
\hline 17 & 2 & 1,2 & 2 & 2 & 2 & 2 & 2 & 2 & 2 \\
\hline 18 & $1,2,3$ & 1,2 & 1,2 & 1 & 1 & 2 & 1 & 1 & 2 \\
\hline 19 & $2,3,6$ & 3,6 & 3 & 3 & 6 & 3 & 3 & 6 & 2 \\
\hline 20 & 1 & 1 & 1 & 1 & 1 & 3 & 3 & 1 & 1 \\
\hline 21 & $1,2,3$ & 2 & 2,3 & 2,3 & 2 & 1 & 3 & 3 & 3 \\
\hline 22 & 3 & $1,3,4$ & 3,4 & 1,3 & 1 & 3 & 3 & 3 & 3 \\
\hline 23 & $3111 \pm 796.9$ & $2425 \pm 571$ & $3690 \pm 585$ & $3233 \pm 11$ & 1915 & 1530 & 3375 & 2450 & 2365 \\
\hline 24 & $23.8 \pm 1.4$ & $22.9 \pm 2.4$ & $24.2 \pm 0.8$ & $25 \pm 1.4$ & 23.5 & 20 & 25.5 & 20.5 & 22 \\
\hline 25 & $18.7 \pm 1.9$ & $19 \pm 2.3$ & $20.8 \pm 1.6$ & $18 \pm 2.8$ & 16 & 16 & 20.5 & 15 & 17 \\
\hline 26 & 2,3 & $1,2,3,4$ & 3,4 & 4,5 & 2 & 3 & 2 & 3 & 2 \\
\hline 27 & $8 \pm 1.6$ & $8.1 \pm 1.1$ & $9.8 \pm 1.0$ & $9 \pm 0.0$ & 7.5 & 8 & 9 & 7.5 & 8 \\
\hline 28 & $3.7 \pm 0.4$ & $3.7 \pm 0.8$ & $3.5 \pm 0.5$ & $3.8 \pm 0.4$ & 4 & 2.5 & 4.5 & 3.5 & 3 \\
\hline 29 & 1 & 1,2 & 1,2 & 2,3 & 1 & 1 & 1 & 2 & 1 \\
\hline 30 & 2 & 2 & 2 & 2 & 3 & 2 & 1 & 2 & 2 \\
\hline 31 & 2,4 & 1,4 & 1,4 & 4 & 4 & 2 & 4 & 1 & 4 \\
\hline 32 & 1,2 & 1,2 & 1 & 1 & 2 & 1 & 1 & 1 & 3 \\
\hline 33 & $115.6 \pm 27.3$ & $130.6 \pm 26.9$ & $118.3 \pm 9.8$ & $138 \pm 0.0$ & 98 & 155 & 124 & 98 & 98 \\
\hline 34 & $25 \pm 3.5$ & $30 \pm 5$ & $26.7 \pm 7.6$ & $22.5 \pm 3.5$ & 30 & 25 & 25 & 25 & 40 \\
\hline
\end{tabular}

The plot of cabbage hybrids on first three PCs obtained from analysis of 34 morphological traits is presented in Figure 3. The scatter diagram of the cabbage hybrids showed that there was high a level of morphological diversity and the cabbage hybrids had significant differences in the important plant traits. 


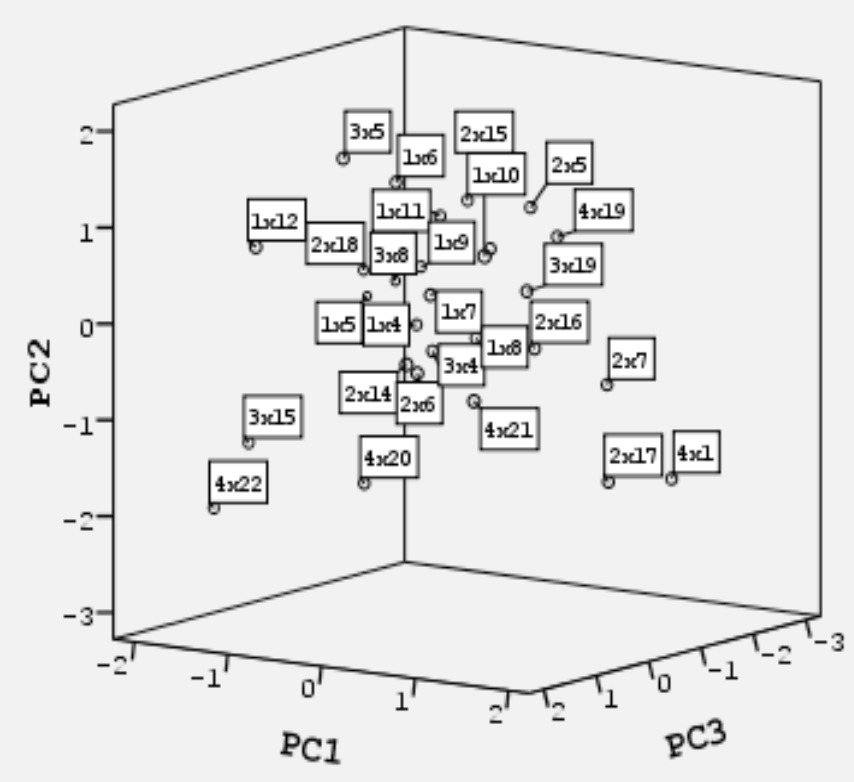

Figure 3. Scatter diagram based on the first three principal component (PC) axes in 28 cabbage hybrids

Scatter diagram of 22 cabbage genotypes for the first three principal components is shown in Figure 4. Genotypes that appear one on the top of the other or coincident on three dimensional graphic are very close or similar in terms of one or a few morphological features. 18 numbered genotype, P 62-1 which obtained from USDA, situated at the top of the PC2 and was clearly separated from other genotypes. This genotype was suitable for sarmalik production because of its leaf characteristics and earliness. It was also used previously as a parent in a breeding program and had high combination ability. As seen in Figure 4, the cabbage parents had a significant variation in morphological plant characteristics. This variation is very important in breeding of hybrid varieties. The lower the degree of relationship between the parents, or the more the genetic distance between them, the higher heterosis occur (Miller and Fick, 1997).

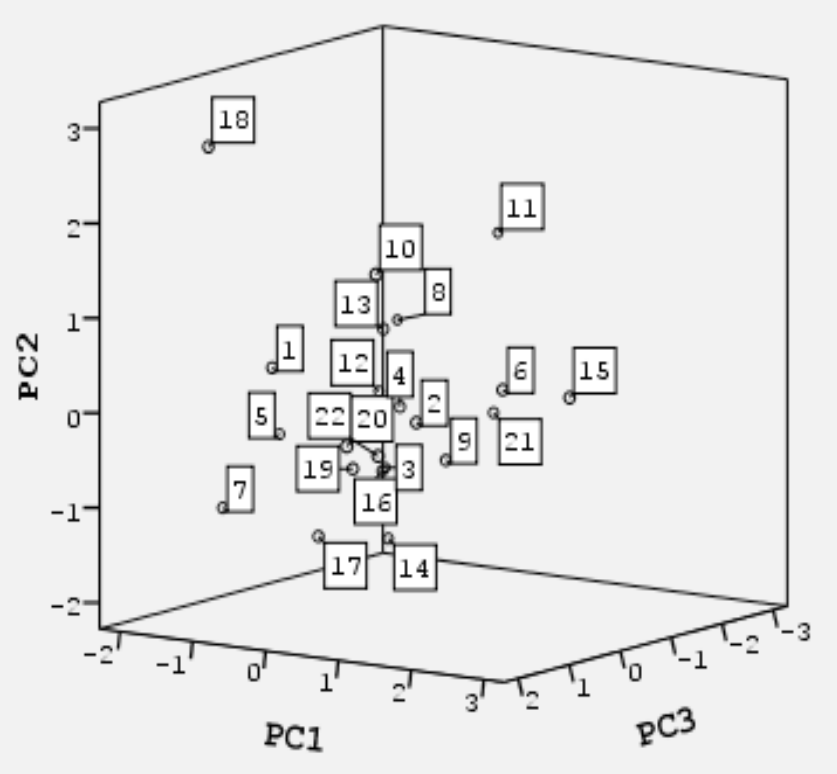

Figure 4. Scatter diagram based on the first three principal component (PC) axes in 22 cabbage parents 


\section{CONCLUSION}

As a result, we have found that the cabbage hybrids and parents had a significant variation in terms of morphological plant characteristics. These findings are important for breeding of hybrid variety studies in the future. In conclusion, this work has contributed to better understanding of variability of the studied characteristics. These characteristics can effect directly registration of new varieties, the market value of new hybrids and recognizable of them by consumers.

\section{ACKNOWLEDGMENTS}

This study was supported by General Directorate of Agricultural Research and Policies of Turkey.

\section{REFERENCES}

Anonim 2010. Meteoroloji Genel Müdürlüğ̈̈. Ankara.

Arslanoglu F, Aytac S, Karaca Oner E, 2011. Morphological characterization of the local potato (Solanum tuberosum L.) genotypes collected from the Eastern Black Sea region of Turkey. African Journal of Biotechnology, 10(6): 922-932.

Balkaya A, Yanmaz R, Apaydin A, Kar H, 2005. Morphological characterization of white head cabbage (Brassica oleracea var. capitata subvar. alba) genotypes in Turkey. New Zealand Journal of Crop and Horticultural Science, 33: 333-341.

Bayraktar K, 1981. Sebze Yetiştirme. Cilt II. Ege Üniversitesi Ziraat Fakültesi Yayınları. No. 169. Bornava, İzmir. $480 \mathrm{~s}$.

Cerqueira-Silva CBM, Cardoso-Silva CB, Conceicao LD, Nonato JVA, Oliveira AC, Corrêa RX, 2009. Comparison of coeffcients and distance measurements in passion fruit plants based on molecular markers and physicochemical descriptors. Genetics and Molecular Research, 8(3): 870879.

Cervenski J, Gvozdanovic-Varga J, Vasic M, Glogovac S, 2010. Multivariate analysis for head weight and yield performance of experimental cabbage hybrids (Brassica oleracea var. capitata L.). Genetika, 42(2): 259-266.

Cervenski J, Gvozdanovic-Varga J, Glogovac S, Dragin S, 2011a. Variability of characteristics in new experimental hybrids of early cabbage (Brassica oleracea var. capitata L.). African Journal of Biotechnology, 10(59): 12555-12560.

Cervenski J, Gvozdanovic-Varga J, Glogovac S, 2011b. Local cabbage (Brassica oleracea var. capitata L.) populations from Serbian Province of Vojvodina. African Journal of Biotechnology, 10(27): 5281-5285.

Crochemore ML, Molinari HBC, Vieira LGE, 2003. Genetic diversity in passion fruit (Passifora spp.) evaluated by RAPD markers. Brazilian Archives of Biology and Technology, 46: 521-527.
Gvozdanovic-Varga J, Gvozdenovic DJ, Vasic M, Cervenski J, 2004. Review of a collection of experimental watermelon hybrids. Proceedings VIII Symposium Biotehnology and Agroindustry, Velika Plana, November 01-03, pp: 226-234.

Hartings H, Berardo N, Mazzinelli GF, Valoti P, Verderio A, Motto M, 2008. Assessment of genetic diversity and relationships among maize (Zea mays L.) Italian landraces by morphological traits and AFLP profiling. Theoretical and Applied Genetics, 117(6): 831-842.

IBPGR, 1990. Descriptors for Brassica and Raphanus. International Board for Plant Genetic Resources, Rome, 51 p.

Jeffers JNR, 1967. Two cases studies in the application of principal component analysis. Applied Statistics, 16: 225-236.

Kar H, Karaağaç O, Kibar B, Apaydın, A, 2008. Beyaz baş lahanada geliştirilen yerli $F_{1}$ hibrit çeşit adaylarının morfolojik özelliklerinin tanımlanması. VII. Sebze Tarımı Sempozyumu, 26-29 Ağustos, Yalova.

Kaygısız Aşçığul T, 2009. Bazı lahana genotiplerinin morfolojik ve moleküler tanımlanmasına yönelik araştırmalar. Yüksek Lisans Tezi, Ege Üniversitesi, Fen Bilimleri Enstitüsü, İzmir, $94 \mathrm{~s}$.

Kendall, M., 1980. Multivariate analysis. Charles Griffin and Co London. $210 \mathrm{p}$.

Lezzoni F, Pritts MP, 1991. Application of principal components analysis to horticulture research. Horticulture, 26(4): 334338.

Liu J, Liu L, Hou N, Zhang A, Liu C, 2007. Genetic diversity of wheat gene pool of recurrent selection assessed by microsatellite markers and morphological traits. Euphytica, 155: 249-258.

Marjanovic-Jeromela A, Marinkovic R, Mijic A, Jankulovska M, Zdunic Z, Nagl N, 2008. Oil yield stability of winter rapeseed (Brassica napus L.) genotypes. Agriculturae Concepectus Scientificus, 73(4): 217-220.

Miller JF, Fick GN, 1997. Sunflower genetics. In: Sunflower Technology and Production (Schneiter AA, ed.). Agronomy Monogram 35, ASA, CSSA and SSSA, Madison, WI, USA, pp: 441-495.

Mohammadi SA, Prasanna BM, 2003. Analysis of genetics diversity in crop plants: salient statical tools and considerations. Crop Science, 43(4): 1234-1248.

Monteiro A, Lunn T, 1998. Trends and perspectives of vegetable brassica breeding world-wide. World Conference on Horticultural Research, Rome (Italy), June 17-20, pp: 90-96.

Rosa EAS, Heaney RK, Fenwick GR, Portas CAM, 1997. Glucosinolates in crop plants. Horticultural Reviews, 19: 99215.

Rohlf FJ, 1992. NTSYS-pc. Numerical taxonomy and multivariate analysis system. Version 1.70. Exeter Software, Setauket, New York. 
Rubatzky VE, Yamaguchi M, 1997. World vegetables: Principles, production, and nutritive values. Chapman \& Hall, NewYork. $572 \mathrm{p}$.

Singh BK, Sharma SR, Kalia P, Singh B, 2010. Character association and path analysis of morphological and economic traits in cabbage (Brassica oleracea var. capitata L.). Indian Journal of Agricultural Sciences, 80(2): 116-118.

Smith JSC, Smith OS, 1989. The description and assessment of distances between inbred lines of maize: The utility of morphological, biochemical and genetic descriptors and a scheme fort He Testing of distinctiveness between Inbred Lines. Maydica, 34: 151-161.

Smykal, P., Hybl, M., Corander, J., Jarkovsky, J., Flavell, A.J., Griga, M., 2008. Genetic diversity and population structure of pea (Pisum sativum L.) varieties derived from combined retrotransposon, microsatellite and morphological marker analysis. Theoretical and Applied Genetics, 117(3): 413-424.

Tanaka N, Niikura S, 2003. Characterization of early maturing $F_{1}$ hybrid varieties in cabbage (Brassica oleracea L.). Breeding Science, 53(4): 325-333.

TÜİK 2015. Türkiye İstatistik Kurumu, Ankara.

UPOV 2004. Cabbage, TG/48/7. Guidelines for the conduct of tests for distinctness, uniformity and stability. International Union For The Protection of New Varieties of Plants, Geneva, $36 \mathrm{p}$.

Van Poppel G, Verhoeven DTH, Verhagen H, Goldbohm RA, 1999.
Brassica vegetables and cancer prevention. Epidemyology and Mechanisms. Advances in Experimental Medicine and Biology, 472: 159-168.

Vasic M, Gvozdanovic-Varga J, Cervenski J, 2008. Divergence in the dry bean collection by principal component analysis (PCA). Genetics, 40(1): 23-30.

Viana A, Souza M, Araújo I, Corrêa R, Ahnert D, 2010. Genetic diversity in Passifora pecies determined by morphological and molecular characteristics. Biologia Plantarum, 54(3): 535538 .

Vural H, Eşiyok D, Duman İ, 2000. Kültür Sebzeleri (Sebze Yetiştirme). Ege Üniversitesi Basım Evi, Bornova, İzmir. 440 s.

Yanmaz R, Kaplan N., Balkaya A, Apaydın A, Kar H, 2000. Türkiye'nin beyaz baş lahana (Brassica oleracea var. capitata subvar. alba) gen kaynaklarının belirlenmesi üzerinde araştırmalar. III. Sebze Tarımı Sempozyumu, 11-13 Eylül, Isparta.

Yousuf M, Ajmal SU, Munir M, Ghafoor A, 2011. Genetic diversity analysis for agro-morphological and seed quality traits in rapeseed (Brassica campestris L.). Pakistan Journal of Botany, 43(2): 1195-1203.

Zhang X, Blair MW, Wang S, 2008. Genetic diversity of Chinese common bean (Phaseolus vulgaris L.) landraces assessed with simple sequence repeat markers. Theoretical and Applied 